\title{
AS FORMAS DE MATERIALIZAÇÃO DAS POLÍTICAS DE EDUCAÇÃO INTEGRAL EM RONDÔNIA
}

\author{
Marco Antônio de Oliveira Gomes ${ }^{1}$ \\ Universidade Estadual de Maringá - UEM \\ Cláudia Barbosa Lôbo ${ }^{2}$ \\ Gedeli Ferrazzo ${ }^{3}$ \\ Universidade Federal de Rondônia - UNIR
}

\section{RESUMO}

O presente artigo se propõe a analisar as formas de materialização das políticas de Educação Integral na Educação Básica do Estado de Rondônia. Trata-se de uma questão importante, na medida em que, precisa ser respondida sem mistificações ou especulações. Para tanto, esse trabalho busca o vínculo histórico entre a concepção de educação integral e o conceito de politecnia. Para alcançarmos tal objetivo direcionamos o levantamento documental e bibliográfico acerca do conceito de educação integral, assim como um levantamento de dados durante o encontro de coordenadores e diretores da rede pública escolar de Rondônia entre 19 e 21 de outubro de 2015, no qual foi aplicado um questionário aberto para 24 coordenadores e 24 diretores, totalizando 48 profissionais que trabalham cotidianamente em escolas que ofertam o Programa Mais Educação. O referencial teórico se fez por meio de uma opção teórica alicerçada em autores como Marx (2003), Marx; Engles (1992; 2007), Maciel (2013), Alves (2006) e Mészáros (2005). Esse referencial serviu de suporte para elaboração do roteiro de observação e para a aplicação do questionário Assim, busca-se responder o problema colocado a partir da análise da percepção daqueles que encontram-se no "chão da escola". Afinal, não basta que se constituam em meros executores de projetos oficiais e responder burocraticamente pela escola ou pelo sistema educacional.

Palavras-chave: Educação Integral. Rondônia. Politecnia.

\section{MATERIALIZATION THE FORMS OF EDUCATION POLICIES IN INTEGRAL RONDÔNIA}

ABSTRACT

This article aims to examine ways of materialization of Integral Education policies in the Basic Education of the State of Rondonia. This is an important issue, to the extent that needs to be answered without mystifications or speculation. Therefore, this work seeks the historical link between the design of comprehensive education and the concept of polytechnic. To achieve this objective we direct the documentary and literature about the concept of integral education, as well as data collection during the meeting of coordinators and directors of public school network Rondonia between 19 and 21 October 2015, in which it applied a open questionnaire to 24 engineers and 24 directors, totaling 48 professionals working daily in schools that offer the More Education Program. The theoretical framework was made by means of a theoretical option rooted in authors such as Marx (2003), Marx; Engles (1992; 2007), Maciel (2013), Alves (2006) and Mészáros (2005). This reference served as support for the preparation of observation guidelines and the questionnaire therefore seeks to answer the problem posed from the perception of the analysis of those who are on the "ground school". After all, it is not enough to constitute mere executors of official projects and respond bureaucratically by the school or the educational system.

Keywords: Integral Education. Rondônia. Polytechnic. 


\section{INTRODUÇÃO}

Ao longo da história da educação ocorreram muitas experiências de educação integral, algumas alicerçadas em concepções pedagógicas identificadas com a burguesia, outras baseadas em concepções socialistas. No caso específico do Brasil, pode-se enumerar experiências de caráter tipicamente assistencialista, outras de cunho filantrópico e confessional, e algumas mantidas pelo poder do Estado.

As experiências mantidas pelo poder público têm enfrentado uma série de obstáculos para sua concretização, quer pela dificuldade de compreensão dos pressupostos pedagógicos por parte dos gestores, quer, ainda, pela falta de recursos financeiros para manutenção e adequação dos espaços escolares para a materialização da educação integral.

Em contrapartida, ressalte-se que as camadas médias, além da burguesia, possuem condições materiais para ofertar uma educação escolar ampliada aos seus filhos, por meio do ensino privado com o acesso a diferentes espaços e oportunidades culturais. Lembre-se também que muitos desses estabelecimentos privados ofertam diferentes atividades extracurriculares em seu contra turno. Dentro da lógica competitiva das relações de mercado que adentram no ambiente escolar, muitas famílias investem na complementação do horário escolar com outras atividades: cursos de idiomas, atividades esportivas, entre outros cursos.

Observa-se, no tocante as políticas públicas para educação escolar, a proclamação da educação integral que congrega a ideia de ampliação de oportunidades complementares de formação e enriquecimento curricular dos alunos. No entanto, sem contaminar-se pela euforia presente nos discursos oficiais, faz-se necessário verificar os limites materiais para sua concretização. Assim sendo, este artigo se propõe a analisar as formas de materialização das políticas de educação integral na Educação Básica do Estado de Rondônia. Trata-se de uma questão importante, na medida em que, precisa ser respondida sem mistificações ou especulações.

A pesquisa foi realizada durante o encontro de coordenadores e diretores da rede pública escolar do Estado de Rondônia entre 19 e 21 de outubro de 2016, em Porto Velho. Foi aplicado um questionário aberto para 24 coordenadores e 24 diretores, totalizando 48 profissionais que trabalham cotidianamente em escolas que ofertam o Programa Mais Educação.

A observação empírica tem de provar, em cada caso particular, empiricamente e sem nenhum tipo de mistificação, a conexão entre a estrutura social e política e a produção. A estrutura social e o Estado provêm constantemente do processo de vida de indivíduos determinados, mas desses indivíduos não como podem aparecer na imaginação própria ou alheia, mas sim tal como realmente são, quer dizer, tal como atuam, como produzem materialmente e, portanto, tal como desenvolvem suas atividades sob determinados limites, pressupostos e condições materiais, independentes de seu arbítrio. (MARX; ENGELS, 2007, p. 93)

Assim, busca-se responder o problema colocado a partir da análise da percepção daqueles que encontram-se no "chão da escola". Afinal, não basta que se constituam em meros executores de projetos oficiais e respondam burocraticamente pela escola ou pelo sistema educacional. Por isso, entende-se que é imprescindível que os educadores envolvidos no projeto possuam um sólido conhecimento sobre o tema. 
Na primeira parte deste texto, buscar-se-á o vínculo histórico entre a concepção de educação integral e o conceito de politecnia. Em seguida, será apresentado uma breve síntese do debate e experiências ocorridas no Brasil, de modo a fornecer elementos para compreensão da trajetória da educação integral no Brasil. O passo seguinte será a análise dos dados coletados que contou com os sujeitos da pesquisa.

\section{A EDUCAÇÃO INTEGRAL E O PRINCÍPIO DA POLITECNIA: APROXIMAÇÕES}

As diferentes concepções de educação integral foram forjadas ao longo dos embates de classes na história. É impossível compreendê-la desvinculando-a das lutas travadas entre os interesses da burguesia e do proletariado. Dessa forma, pensar a educação integral pressupõe algumas questões: quais seriam os objetivos que sintetizariam as diretrizes da educação integral? Para responder a questão em pauta faz-se necessário uma breve síntese histórica de forma a desvelar os determinantes históricos presentes no processo de expansão da escola pública no continente europeu.

Sobre o progressivo processo de difusão da escola no "velho continente", faz-se necessário observar que o empenho por parte do Estado ocorreu somente no último quartel do século XIX, cuja realização se efetivou apenas nas regiões de capitalismo mais avançado. No entanto, ao mesmo tempo em que ocorria a expansão da rede escolar, encontramos em segmentos do movimento operário a recusa em aceitar o projeto de educação burguesa que reforçava a alienação originária das relações de produção.

Ora, se a expansão da educação pública se fez com maior intensidade nas últimas décadas do século XIX como instituição progressivamente regulada pelo Estado com objetivo disciplinador e de formação do trabalhador adaptado aos interesses da burguesia que se consolidava como classe dominante, verifica-se um cenário de brutal exploração da força de trabalho infantil nas indústrias no período anterior. Alves (2006), ao analisar as origens históricas da produção da escola pública, argumenta que por força da simplificação do trabalho decorrente da Revolução Industrial, ocorreu a incorporação maciça de mulheres e crianças na produção fabril. A exploração brutal do trabalho e os baixos salários, gerados fundamentalmente pela grande oferta de força de trabalho, determinaram a sujeição dos trabalhadores.

Não é demasiado acrescentar que uma das características marcantes do capitalismo é a escassez em meio a abundância, ou seja, a riqueza concentrada nas mãos da burguesia é fruto do material do trabalho produzido pelo trabalhador que não a usufrui. No processo de consolidação das relações capitalistas ficava cada vez mais evidente a destruição da unidade entre teoria e prática iniciada nos primórdios da produção manufatureira.

A medida em que a maquinaria prescinde de força muscular, torna-se
meio de utilizar operários sem força muscular ou com um
desenvolvimento imaturo do corpo, mas com maior flexibilidade dos
membros. Trabalho feminino e infantil foi, assim, a primeira palavra de
ordem no emprego capitalista da maquinaria! Esse poderoso meio de
substituição do trabalho e operários transformou-se, assim, logo num
meio de multiplicar o número de assalariados, colocando todos os
membros da família operária, sem diferença de sexo nem de idade, sob
a tutela imediata do capital. O trabalho coercitivo para o capitalista
usurpou não só o lugar no círculo doméstico, dentro de barreiras éticas,
para a própria família [...].
Continua a ocorrer na Inglaterra que mulheres "tiram crianças do asilo 
de pobres (workhouse) e alugam-nas a qualquer um por 2 xelins e 6 pence por semana". Apesar da legislação, pelo menos 2 mil jovens na Grã-Bretanha são vendidos pelos próprios pais como máquinas limpachaminés vivas (embora existam máquinas para substituí-los) [...].

Já anteriormente aludimos à deterioração física das crianças e os jovens, bem como das mulheres operárias, que a maquinaria submete à exploração do capital, primeiro diretamente, nas fábricas que medram na base dela, e, depois, indiretamente, em todos os restantes ramos de indústria. Por isso, detenhamos-nos aqui apenas num ponto: a monstruosa mortalidade dos filhos dos operários nos seus primeiros anos de vida (MARX, 2013, p. 99-103).

Assim, o período que se seguiu foi caracterizado pela intensificação das lutas operárias, cujos embates amadureceram a consciência de classe em um momento de recrudescimento das disputas internas, travadas entre diferentes frações da burguesia. A legislação social que surgiu na Inglaterra do período, em grande parte, foi produto das pressões da classe operária e das lutas e divisões internas da burguesia (ALVES, 2006).

Se no período anterior ao processo de consolidação do capitalismo, o ensino de vertente religiosa constitui-se em um dos instrumentos de manutenção do poder, mas a partir do processo de industrialização e de intensificação das lutas operárias que surgem as novas propostas educacionais com vistas à manutenção do poder crescente burguês.

Nesse movimento, o dualismo que marcava a escola burguesa, produzida no final do século XVIII e primeira metade do século XIX por pedagogos como Pestalozzi, Filangieri, Basedow e Herbart, também se revelava superando em face do novo estágio de desenvolvimento das forças produtivas. Esses pedagogos, depois de terem reconhecido a existência das classes sociais, justificaram a criação de dois tipos de escolas que refletiam e reforçavam, ao mesmo tempo, a estratificação social: uma para os filhos de trabalhadores, de caráter profissionalizante, e outra para os filhos dos dirigentes da sociedade, fundada nas artes liberais e nas ciências modernas. Porém, ao final do século XIX, ia ficando cada vez mais evidente que as escolas técnicas de caráter profissionalizante, a exemplo das escolas de artes e ofícios, vinham se tornando obsoletas diante do desenvolvimento tecnológico e da simplificação crescente do trabalho. O processo de trabalho, quanto mais dominado pela maquinaria moderna, menos dependente tornava-se da habilidade do trabalhador (ALVES, 2006, p. 141-142).

Não por acaso, o discurso reformista do período colocou como necessário a qualificação do trabalhador como requisito para sua inserção no mundo do trabalho. No entanto, o que os reformadores burgueses "esquecem-se" ou ignoram é que o desemprego é uma necessidade para a exploração do capital sobre o trabalho.

Observe-se os apontamentos de Marx antes de prosseguirmos:

Como máquina, o meio de trabalho torna-se logo concorrente do próprio operário. A automatização do capital através da máquina está na razão direta com o número de operários, cujas condições de existência ela aniquila. Todo o sistema de produção capitalista assenta no fato de o operário vender sua força de trabalho como mercadoria. [...] A parte da classe operária que a maquinaria transforma em população supérflua, i.e., já não imediatamente necessária para a auto valorização do capital, por um lado sucumbe na luta desigual do velho funcionamento artesanal e 
manufatureiro contra o [funcionamento] mecanizado; por outro lado, sobre inunda todos os ramos da indústria mais facilmente acessíveis, superlota o mercado de trabalho e faz, portanto, descer o preço da força de trabalho abaixo de seu valor (MARX, 2013, p. 146-7).

Não há como negar que os estudos de Marx sobre o capital continuam atuais. Não obstante todos os avanços ocorridos no campo científico e dos direitos conquistados, atualmente verifica-se uma ofensiva contra os direitos dos trabalhadores, intensificando a carga de trabalho sobre seus ombros. Ao invés de facilitar a sobrevivência de todos, observa-se o contrário, tal qual aponta Mészáros:

Vivemos numa ordem social na qual mesmo os requisitos mínimos para a
satisfação humana são insensivelmente negados à maioria da
humanidade, enquanto os índices de desperdício assumiram proporções
escandalosas, em conformidade com a mudança da reivindicada
destruição produtiva, do capitalismo no passado, para a realidade, hoje
predominante, da produção destrutiva (MÉSZÁROS, 2005, p. 73).

As contradições do capitalismo em escala global demonstram sua incapacidade civilizatória enquanto elemento organizador da força de trabalho. A reprodução de sua existência funda-se no desperdício, no desemprego e, por consequência, na pobreza de milhões de seres humanos deixados a sua própria sorte.

Ora, como não há interesse em desvelar as razões estruturais da desigualdade, a educação surge como solução para os problemas sociais. Porém, uma das possibilidades de luta pela superação das contradições presentes reside na integração entre trabalho e educação. Tal integração, sob o viés de uma perspectiva marxiana, designa-se como educação politécnica ou formação omnilateral. Sobre a questão educação politécnica, há concordância, entre os pesquisadores da área de trabalho e educação, que o conceito foi elaborado originalmente por Marx, na segunda metade do século XIX. Contudo, faz-se necessário acrescentar que se Marx esboçou os princípios da educação politécnica, o autor não se dedicou a trabalhos sistematizados a respeito da questão pedagógica.

Assim, a educação omnilateral, segundo a perspectiva de Marx, objetivava a formação abrangente.

Por educação entendemos três coisas:

1. Educação intelectual.

2. Educação corporal, tal como a que se consegue com os exercícios de ginástica e militares.

3. Educação tecnológica, que recolhe os princípios gerais e de caráter científico de todo o processo de produção e, ao mesmo tempo, inicia as crianças e os adolescentes no manejo de ferramentas elementares dos diversos ramos industriais (MARX \& ENGELS, 2004, p. 68).

Em outras palavras, a integração entre educação e trabalho apresentava como objetivo a superação da alienação crescente por meio de um tripé básico: educação intelectual (cultura geral), educação física e ensino técnico polivalente (técnico e científico). Por meio da proposição da educação politécnica buscava-se superar a formação unilateral, especializada e alienada.

Ora, se a classe trabalhadora, por si só, não conquista sua consciência de classe, por ser privada dos meios de produção e dos meios de acesso ao saber expropriado pela burguesia, a educação surge como um meio possível de acesso ao conhecimento sistematizado e de luta pela transformação das relações sociais. Por isso o papel estratégico 
da escola e da educação integral para a construção da consciência de classe do proletariado.

Nessa perspectiva, encontra-se a gênese do trabalho como princípio educativo, que objetiva a transformação da sociedade. Conforme os apontamentos de José Rodrigues, em um verbete sobre Educação Politécnica, encontramos em Marx os fundamentos do trabalho como princípio educativo:

1. Educação pública, gratuita, obrigatória e única para todas as crianças e jovens, de forma a romper com o monopólio por parte da burguesia da cultura, do conhecimento. 2. A combinação da educação (incluindo-se aí a educação intelectual, corporal e tecnológica) com a produção material com o propósito de superar o hiato historicamente produzido entre trabalho manual (execução, técnica) e trabalho intelectual (concepção, ciência) e com isso proporcionar a todos uma compreensão integral do processo produtivo.3. A formação omnilateral (isto é, multilateral, integral) da personalidade de forma a tornar o ser humano capaz de produzir e fruir ciência, arte, técnica. 4. A integração recíproca da escola à sociedade com o propósito de superar a estranhamento entre as práticas educativas e as demais práticas sociais.

Como se vê, trata-se de uma proposta de educação que contempla a formação intelectual, corporal e tecnológica, constituída sob um processo de produção técnicocientífico. Dessa forma, os conteúdos disciplinares devem ser trabalhados como meios de compreensão da realidade material e das necessidades de superação da sociedade de classes. Em outras palavras, a educação politécnica fundamenta-se na concepção de que o homem é um ser histórico cultural, constituído a partir de sua práxis social (na qual o trabalho é o fundamento determinante e a consciência sua expressão), cujo desdobramento é o desenvolvimento potencial de suas múltiplas capacidades cognitivas, físicas e sociais (MACIEL, 2013, p. 134). Dessa forma, a concepção de educação presente em Marx aponta para a formação integral com instrumento de superação da divisão entre trabalho manual e trabalho intelectual. Por outro lado, há que se destacar que a educação politécnica somente poderá efetivar-se em turno integral, em um espaço apropriado, porque ambientado para proporcionar formas de sociabilidade e de formação integral.

Diante do exposto, cabe ressaltar que na sociedade capitalista contemporânea, a educação tende a reproduzir as concepções burguesas de sociedade. Nesse sentido, cabenos analisar as proposições para educação integral presentes no Brasil, não sem antes indicar alguns aspectos da construção histórica das concepções de educação integral em nosso país.

\section{BREVE SÍNTESE SOBRE AS CONCEPÇÕES DE EDUCAÇÃO INTEGRAL NO BRASIL}

A proposição de educação integral ou educação em tempo integral não são novidades em nosso país. No Manifesto dos Pioneiros da Educação Nova, publicado em 1932, a escola integral e única era apresentada como antítese à escola tradicional.

A educação nova, alargando sua finalidade para além dos limites das classes, assume, com uma feição mais humana, a sua verdadeira função social, preparando-se para formar a "hierarquia democrática" pela "hierarquia das capacidades", recrutadas em todos os grupos sociais, a que se abrem as mesmas oportunidades de educação. Ela tem, por 
objetivo organizar e desenvolver os meios de ação durável com o fim de dirigir o desenvolvimento natural e integral do ser humano em cada uma das suas etapas de seu crescimento, de acordo com uma certa concepção de mundo (MANIFESTO DOS PIONEIROS, 1932).

Cabe destacar que a educação integral, defendida pelo movimento renovador, se ancorava na orientação político-filosófica da concepção humanista moderna, pautada no ideal da crença do progresso da ciência, do racionalismo científico e da democracia, concebendo o homem como um ser integral.

Dentro das fileiras que engrossaram o movimento pela defesa do escolanovismo encontra-se a figura de Anísio Teixeira, um dos signatários do Manifesto, que ao defender a implementação de um sistema público de ensino para o país, propôs uma educação em que a escola ofertasse às crianças:

[...] seu programa completo de leitura, aritmética e escrita, e mais ciências físicas e sociais, e mais artes industriais, desenho, música, dança e educação física [...] saúde e alimento à criança, visto não ser possível educá-la no grau de desnutrição e abandono em que vive (TEXEIRA, 1959, p.79).

No mesmo texto, Anísio reforça sua visão de instituição escolar pública:

[...] que a escola eduque, forme hábitos, forme atitudes, cultive aspirações, prepare, realmente, a criança para a sua civilização - esta civilização tão difícil por ser uma civilização técnica e industrial e ainda mais difícil e complexa por estar em mutação permanente (TEXEIRA, 1959, p.79).

As proposições de Anísio Teixeira apontavam para as crianças dos anos iniciais do ensino fundamental, que deveriam receber uma formação completa da escola, alicerçada em atividades artísticas, físicas, intelectuais, profissionais, de saúde, além do aspecto voltado para a formação de hábitos e atitudes. Nesse sentido, cabe enfatizar que a proposta de Teixeira para educação não pode ser desvinculada do ideário desenvolvimentista que atravessou o país nos anos 1950. Em outras palavras, a formação completa dos alunos seria um elemento de formação do adulto civilizado e pronto para inserção na sociedade industrial.

[...] a escola deve ser uma réplica da sociedade a que ela serve, urge reformar a escola para que ela possa acompanhar o avanço "material" de nossa civilização e preparar uma mentalidade que moral e espiritualmente se ajuste com a presente ordem de coisas (TEIXEIRA, 1968, p. 42).

Acrescente-se que é possível identificar outras manifestações e experiências proclamadas como educação integral, tanto em instituições privadas de ensino que trabalharam em tempo integral, além de outras experiências organizadas pelo Estado, destacando-se o Centro Educacional Carneiro Ribeiro, concebido por Anísio Teixeira, inspirando-se nas propostas de John Dewey, que afirmava a necessidade de oportunidades para que crianças e adolescentes vivenciassem, por meio da experiência, o modo de vida democrático, com vistas assegurar a própria democracia e o desenvolvimento.

Inaugurada, parcialmente, em 21 de outubro de 1950, o Centro Educacional Carneiro Ribeiro, pretendia-se restituir o dia letivo completo, com programas de "aritmética e escrita e mais ciências físicas e sociais, e mais artes industriais, desenho, 
música, dança e educação física" para combater a simplificação ocorrida nas escolas primárias brasileiras, nas primeiras décadas do século XX, com a defesa clara da necessidade de sua universalização (TEIXEIRA, 1977, p. 140-141).

A experiência de Teixeira serviu de parâmetro para outras que a sucederam com destaque para os CIEPs, implantados sob iniciativa de Darcy Ribeiro no Rio de Janeiro durante as gestões de Leonel Brizola (1983-1986) e (1991-1994). Em uma breve síntese, é possível afirmar que Ribeiro entendia a escola como seletiva e elitista em sua estrutura e proposições, além de não estar preparada para receber aqueles não tiveram acesso aos bens materiais e simbólicos da sociedade moderna. Por isso, defendeu a escola de horário integral, fundamentalmente para as crianças provenientes das famílias de baixa renda (RIBEIRO, 1984). Acrescente-se que os CIEPs constituíram-se em um projeto de escola de período integral destinado a atender a infância. As unidades foram construídas preferencialmente nas regiões habitadas por trabalhadores de baixa renda, projetadas para funcionarem em turno integral, com atividades curriculares, orientação pedagógica, esportes, eventos culturais e alimentação.

Além dessas experiências e outras que se seguiram, católicos, integralistas e anarquistas conceberam diferentes formas de educação integral na primeira metade do século XX. Nesse sentido, as diferentes proposições a respeito da educação integral não devem ser compreendidas desvinculadas de um projeto de classe e sociedade.

De forma análoga, o conceito de politecnia, tomando como referência que o propósito da educação integral, na perspectiva de uma educação socialista já havia sido abordado em um trabalho de Paschoal Lemme em 1955, depois de uma viagem à União Soviética, quando descreveu suas observações a respeito da educação. Na obra, Lemme cita Sidney e Beatrice Webb, que escreveram sobre os objetivos da educação politécnica

O que a escola politécnica procura [...] é justamente o oposto de adestramento para determinado ofício ou profissão; de fato, visa-se um aperfeiçoamento intelectual de todos os alunos [...], não se procurando saber as determinadas profissões que escolherão de per si [...]. Essa ocupação pode ser em um trabalho manual ou numa profissão intelectual (LEMME, 1955, 74).

Diante do exposto, é possível afirmar que a temática da educação integral não é novidade por aqui. Porém, o senso comum acaba por não diferenciar as diferentes proposições a respeito da educação integral. Nesse aspecto, é importante observar que o senso comum aponta que a ampliação do tempo escolar é a materialização da educação integral e, ao mesmo tempo, uma forma de "manter os jovens afastados das ruas" ampliando a jornada escolar. De forma sintética poderíamos afirmar que trata-se de um discurso reincidente que apresenta como solução para os problemas sociais, materializando políticas e programas educacionais assistencialistas.

Observe-se também a existência de propostas implantadas em diferentes municípios e estados, de escolas de ensino fundamental, com jornadas ampliadas ou de tempo integral e proposições de educação integral com a adoção de atividades socioeducativas complementares à aprendizagem dos alunos, algumas desenvolvidas por ONG's que buscam a articular-se com a escola pública. Vale lembrar o dispositivo legal, Lei 9.394 (LDB, 1996) que constitui as diretrizes e bases da educação nacional, em seu Artigo 34, Parágrafo Segundo:

Artigo 34. A jornada escolar no ensino fundamental incluirá pelo menos quatro horas de trabalho efetivo em sala de aula, sendo progressivamente ampliado o período de permanência na escola. [...] $§ 2^{\circ}$. O ensino 
fundamental será ministrado progressivamente em tempo integral, a critério dos sistemas de ensino (BRASIL, 1996).

Dessa forma, uma das iniciativas adotadas pelo governo federal, com objetivo proclamado de alavancar a qualidade da educação nas escolas públicas, foi a criação do Programa Mais Educação (PMEd). Com início no segundo mandato presidencial de Luís Inácio Lula da Silva e ampliado na gestão de Dilma Rousseff, o programa foi instituído por meio da Portaria Interministerial $\mathrm{n}^{\mathrm{o}} 17$ (Brasil. MEC; MDS; ME; MC, 2007) e regulamentado pelo Decreto ${ }^{\circ} 7.083 / 2010$.

De forma sintética, é possível afirmar que o Programa Mais Educação (PMEd), como uma das ações do Plano de Desenvolvimento da Educação, materializa-se em uma política pública que se apresenta como Educação Integral. Criado como política de ação contra a exclusão social, pobreza e a marginalização cultural, o programa propõe que a ampliação do tempo e espaços educativos, por meio da gestão intersetorial, é a solução para a questão da qualidade e fator de inclusão social (BRASIL. MEC, 2007).

Ora, a direção que assume a Educação Integral nas políticas de Estado não é "neutra" ou inocente. Sem dúvida, traz a marca dos conflitos de classe que se materializam no âmbito do conjunto das relações sociais. Trata-se de uma relação que é componente da luta pela hegemônica entre capital e trabalho. No endereço eletrônico da Secretaria de Educação de Rondônia, verifica-se, por exemplo, a presença da educação escolar como redução da pobreza sem questionar as razões de sua existência.

No Estado de Rondônia, sob a coordenação da Secretaria de Estado da Educação, desde o início de 2012, verifica-se a implementação de forma gradativa nas escolas da rede pública de ensino o "Projeto Guaporé de Educação Integral", que tem como umas das justificativas ${ }^{4}$ :

O projeto Guaporé de Educação Integrada começou a ser discutido no estado em 2011, e implantado dois anos depois. Pelo menos 19 escolas em 13 municípios foram beneficiadas com a educação integral, que prioriza bairros ou regiões com maior vulnerabilidade social e com menores índices de desenvolvimento escolar, utilizando a educação como instrumento de diminuição da pobreza, oferecendo ao estudante uma jornada escolar ampliada, dando a eles os suportes necessários para permanecer no ambiente escolar, como alimentação, cultura, esporte e lazer. Mas tem esbarrado em algumas dificuldades, como a presença de profissionais para acompanhar as atividades dos estudantes beneficiados pela educação integral, que passa da casa dos 11 mil alunos (SECRETARIA DE ESTADO DA EDUCAÇÃO DE RONDÔNIA, 2013).

Não se trata de questionar a ampliação da jornada escolar ou das funções da escola, mas de perceber o conteúdo e a forma como ocorre. Em um cenário marcado pela hegemonia das proposições neoliberais, a escola mais uma vez é apresentada como solução para a crise social. Não por acaso, verificam-se proposições de ampliação das funções da escola a partir da lógica regida pelo capital. Assim, observa-se a incorporação de ações de proteção social como um desdobramento da redução das políticas sociais que utilizam o espaço escolar como meio de garantir certas condições de controle sobre os filhos da classe trabalhadora.

No entanto, diferentemente daquilo que é proclamado nos discursos oficiais, a expansão do tempo escolar não se faz com garantias mínimas para o desenvolvimento do trabalho pedagógico. Em diferentes casos, as atividades assumidas pelas escolas não têm 
sido plenamente realizadas por falta de espaço ou de professores, mas servem perfeitamente para dissimular as omissões do Estado. Ainda que o governo federal se apresente na figura de indutor, não há garantias objetivas essenciais ao desenvolvimento da educação integral.

Não bastasse a ausência de condições necessárias para o trabalho docente nas escolas, verifica-se o desconhecimento dos diferentes significados sobre a educação integral por parte dos coordenados e diretores das instituições de ensino. Dessa forma, diante da hegemonia liberal no âmbito das políticas de Estado, como compreender o direito à educação do ponto de vista do trabalhador? Seria o Estado, representante em última instância, dos interesses do capital, o promotor de uma educação politécnica? Qual o interesse do Estado em promover uma educação que contemple uma formação omnilateral dos filhos da classe trabalhadora? Ora, um estudo sobre as formas de educação ofertadas pelo Estado burguês aponta que o capitalismo educa para a subordinação à disciplina do trabalho sob a lógica do capital.

Por isso, é necessário ter clareza que os modelos de educação integral não são homogêneos, mas representam concepções epistemológicas diferentes. Isto posto, a seguir apresentaremos as formas pelas quais ocorre a materialização da "educação integral" no estado de Rondônia por meio da percepção de Diretores e Coordenadores das unidades escolares.

\section{A PERCEPÇÃO DE DIRETORES E COORDENADORES DA REDE ESTADUAL DE ENSINO DE RONDÔNIA A RESPEITO DA EDUCAÇÃO INTEGRAL E SUA MATERIALIZAÇÃO NA ESCOLA}

Quando se defende a centralidade do trabalho como princípio educativo, se faz necessário questionar em que circunstâncias o trabalho é educativo. Isso significa que não é possível pensá-lo abstratamente, fora das condições materiais de produção. Da mesma forma, quando se discute a educação integral, uma pergunta se coloca: qual o modelo de educação integral?

Em A Ideologia Alemã, Marx e Engels indicam que a História possui uma especificidade que independe das representações que dela façam os sujeitos. Não importam o que dizem ou pensam, mas sim a atividade prática.

As premissas de que partimos não têm nada de arbitrário, nem algum tipo de dogma, mas premissas reais, das quais só é possível fazer abstração na imaginação. São os indivíduos reais sua ação e suas condições materiais de vida, tanto aquelas com que se deparam, como aquelas engendradas pela sua própria ação e suas condições materiais de vida, tanto aquelas com que se deparam, como aquelas engendradas pela sua própria ação. Essas premissas podem ser comprovadas, consequentemente, pela via puramente empírica (MARX e ENGELS, 2007, p. 65).

Dessa forma, é possível afirmar que o que define o homem são suas condições concretas de existência, e, assim, a primeira premissa de que se parte na compreensão da condição humana é a "existência de indivíduos". Por meio deste método de análise impõese partir sempre do particular para o geral, partindo de um dado empírico e concreto, mas é necessário ultrapassar o nível da superfície, da aparência imediata para alcançar a essência.

Cumpre acrescentar que toda produção humana, incluindo a educação, são realizadas por homens e mulheres determinados, não como obra do acaso, mas de acordo com as condições concretas que estão dadas em determinado momento histórico. Não 
importa o que os homens dizem ou pensam, mas sim o que produzem. Em outras palavras, não importa o que o discurso oficial proclama como educação integral, mas a forma como ela se materializa na prática.

Isto posto, o pesquisador deve partir da distinção fundamental entre o fato comprovável e a ficção, entre as declarações oficiais a respeito dos Programas de Educação integral e as evidências que comprovem sua materialização. Assim, buscou-se investigar a compreensão de diretores e coordenadores das unidades escolares, acerca da concepção de Educação Integral que orienta as políticas educacionais e as formas de sua materialização no "chão da escola" em um cenário histórico marcada pela crise estrutural do capitalismo e norteada pela ideologia liberal, com profundas repercussões educativas.

Isto posto, as entrevistas realizadas com os coordenadores e diretores da educação básica de Rondônia apresentam, obviamente, uma série de limitações, entre as quais, a distância entre o que foi declarado pelos participantes e aquilo que ocorre na materialização da educação integral. Porém, se a tarefa é difícil, há que se considerar o levantamento de algumas hipóteses acerca das múltiplas concepções sobre educação integral dos entrevistados, fornecendo assim, um conjunto de argumentos capazes de estimular o debate acadêmico.

Observe-se agora, a compreensão de 24 diretores e 24 coordenadores de escolas da rede estadual de Rondônia, acerca da concepção de Educação Integral que orienta as políticas educacionais.

QUADRO 01 Compreensão dos coordenadores acerca da Concepção de Educação Integral presente nas políticas educacionais

\begin{tabular}{|l|l|}
\hline Participante & $\begin{array}{l}\text { A concepção de Educação Integral presente na legislação brasileira } \\
\text { compreende o ser humano em suas múltiplas dimensões e como sujeito } \\
\text { de direitos. No seu entendimento o quê, efetivamente, isso significa? }\end{array}$ \\
\hline Coordenador 1 & $\begin{array}{l}\text { Trabalhar para desenvolver as habilidades e competências do indivíduo, } \\
\text { isso é necessário oferecer diferentes atividades educacionais dos mesmos. }\end{array}$ \\
\hline Coordenador 2 & $\begin{array}{l}\text { Que o ensino aprendizagem precisa acontecer de forma integral, não } \\
\text { importa se ele esta na escola em tempo integral ou parcial. }\end{array}$ \\
\hline Coordenador 3 & $\begin{array}{l}\text { Que a escola deixa de oferecer somente o estudo sistematizado centrado no } \\
\text { professor para oferecer múltiplas opções de educação. }\end{array}$ \\
\hline Coordenador 4 & $\begin{array}{l}\text { Ampliar seus conhecimentos, visto que 4 aulas diárias são insuficientes } \\
\text { para abarcar o conteúdo necessário para uma educação de qualidade. }\end{array}$ \\
\hline Coordenador 5 & $\begin{array}{l}\text { Significa garantir ao aluno a continuidade, bem como, amplitude de } \\
\text { toda vivência, conhecimento e informação que o indivíduo tem acesso no } \\
\text { seu cotidiano. Dentro e fora do âmbito escolar. }\end{array}$ \\
\hline Coordenador 6 & $\begin{array}{l}\text { Que o aluno de estar integrado as múltiplas dimensões da vida e não } \\
\text { somente o acesso ao mercado de trabalho. }\end{array}$ \\
\hline
\end{tabular}

Fonte: Elaborado pelos pesquisadores

$\mathrm{Na}$ verdade, o que se vê, a partir das informações cedidas pelos entrevistados, é uma concepção restrita e fragmentária a respeito do tema, fruto de um processo aligeirado de formação de professores como se denota nas respostas. Na verdade, o desconhecimento do passado, ou mais precisamente da temática da educação integral, não é um fenômeno isolado, mas um problema presente em nossa sociedade.

A destruição do passado - ou melhor, dos mecanismos sociais que vinculam nossa experiência pessoal à das gerações passadas - é um dos fenômenos mais característicos e lúgubres do final do século XX. Quase todos os jovens de hoje crescem numa espécie de presente contínuo, sem 
qualquer relação orgânica com o passado público da época em que vivem. Por isso os historiadores, cujo ofício é lembrar o que outros esquecem, tornam-se mais importantes que nunca no fim do segundo milênio (HOBSBAWM, 1995, p.13).

Nesse cenário, que certamente apresenta forte influência no âmbito da formação de professores, a subjetividade e o relativismo ganham proeminência. Não por acaso, verificase a fragilidade do conhecimento acerca da educação integral, fato que se repete nas respostas dos diretores das unidades escolares.

QUADRO 02 Compreensão dos diretores acerca da Concepção de Educação Integral presente nas políticas educacionais

\begin{tabular}{|c|c|}
\hline Participantes & $\begin{array}{l}\text { A concepção de Educação Integral presente na legislação brasileira } \\
\text { compreende o ser humano em suas múltiplas dimensões e como sujeito } \\
\text { de direitos. No seu entendimento o quê, efetivamente, isso significa? }\end{array}$ \\
\hline Diretor 1 & $\begin{array}{l}\text { O desenvolvimento do indivíduo de forma ampla a fim de que seu } \\
\text { conhecimento contribua para o exercício da sua cidadania. }\end{array}$ \\
\hline Diretor 2 & $\begin{array}{l}\text { Até compreende, no entanto, há dificuldades em relação a execução: trata-se } \\
\text { das questões necessárias à preparação dos RH e instalações. }\end{array}$ \\
\hline Diretor 6 & Educação integral é quando o aluno fica dois períodos na sala (escola). \\
\hline Dire & $\begin{array}{l}\text { Na minha concepção seria muito bom desde que o poder público em primeiro } \\
\text { lugar fizesse as adequações adequadas nas escolas para depois ser } \\
\text { implantadas; não como está sendo feito de qualquer jeito e os gestores que se } \\
\text { vire para a realização; sem espaço, sem funcionamento etc. }\end{array}$ \\
\hline & $\begin{array}{l}\text { ignifica ter escolas com estruturas físicas e pedagógicas para atender alunos } \\
\text { om tempo integral, acredito que deveria priorizar língua portuguesa e } \\
\text { hatemática ampliando a carga horária em laboratórios com aulas práticas. }\end{array}$ \\
\hline Diretor 15 & $\begin{array}{l}\text { a um conhecimento para uma prática educacional que modifique uma } \\
\text { e existente. }\end{array}$ \\
\hline Diretor 16 & $\begin{array}{l}\text { A legislação contempla o ser humano sim em suas diferentes dimensões, este } \\
\text { contexto facilita sua formação como ser humano e aprimora seus } \\
\text { conhecimentos. }\end{array}$ \\
\hline Diretor 18 & tato, mas isso nao acontece. \\
\hline
\end{tabular}

Fonte: Elaborado pelos pesquisadores.

De forma sintética é possível afirmar que as respostas obtidas por meio do questionário expressam o entendimento que muitos diretores possuem a respeito da educação integral, percebendo-se como se constitui a educação integral em muitas escolas de Rondônia. Chama atenção à existência de interpretações que descrevem tal concepção como sinônimo de permanência do aluno nos dois turnos escolares, ou ainda, como " $O$ desenvolvimento do indivíduo de forma ampla a fim de que seu conhecimento contribua para o exercício da sua cidadania". Ora, o que significa o exercício da cidadania em uma sociedade marcada pelo antagonismo de classes? Seria o exercício da abstrata cidadania burguesa?

Por isso, retomar a discussão da educação integral, sob a perspectiva da politecnia, torna-se uma necessidade para aqueles que não se sentem contemplados com as proposições pós-modernas que insistem em afirmar a superação da centralidade do trabalho nas relações sociais, especialmente na educação.

Por outro lado, percebe-se também as condições precárias de efetivação da educação integral na região, afinal para um dos diretores "seria muito bom desde que o 
poder público em primeiro lugar fizesse as adequações adequadas nas escolas para depois ser implantadas; não como está sendo feito de qualquer jeito e os gestores que se vire para a realização; sem espaço, sem funcionamento etc. ”. Ora, não se faz educação integral sem recursos e com improvisações que se materializam nas dificuldades em relação a execução do trabalho: recursos humanos e prédios com instalações adequadas.

Assim, quando se observa a proliferação de experiências proclamadas como educação integral, constata-se que o discurso das políticas oficiais esbarra nos meios de torna-la realidade. Por isso, o desafio é a construção de unidades escolares com espaços para o desenvolvimento das potencialidades das capacidades humanas (MACIEL, 2013).

Desse modo, diante do que já foi exposto, que a educação integral implica em uma escola, cuja estrutura e espaços educativos atendam minimamente às necessidades dos processos pedagógicos. Ora, a viabilização dos processos pedagógicos também é decorrente do trabalho do gestor e de sua equipe. Como decorrência dessa exigência, a equipe gestora não pode prescindir dos conhecimentos pedagógicos. Isto posto, vejamos as ações tomadas por coordenadores e diretores das unidades escolares para efetivação do programa em suas respectivas unidades.

QUADRO 02 - Gestão Escolar na Educação Integral- Coordenadores

\begin{tabular}{|c|c|}
\hline Participantes & $\begin{array}{l}\text { A dinâmica da implementação de um Programa de Educação Integral } \\
\text { requer diversas ações, dentre elas, a reformulação do Projeto Político } \\
\text { Pedagógico da escola. Cite as que você como Gestor/Coordenador } \\
\text { desenvolveu para a efetivação do referido Programa. }\end{array}$ \\
\hline Coordenador 01 & $\begin{array}{l}\text { Implantação no PPP não ocorreu efetivamente, porém ações de planos } \\
\text { para facilitar o trabalho dos monitores elaborando um plano de curso } \\
\text { referência e currículo. }\end{array}$ \\
\hline Coordenador 02 & $\begin{array}{l}\text { Conhecer os programas e os eixos a serem desenvolvidos, reestruturação } \\
\text { do PPP, parceiros com a comunidade em torno da escola. }\end{array}$ \\
\hline Coordenador 03 & $\begin{array}{l}\begin{array}{l}\text { Integrar as disciplinas do currículo; planejamento pedagógico; } \\
\text { democratização da escola. }\end{array} \\
\end{array}$ \\
\hline Coordenador 04 & $\begin{array}{l}\text { Foi feito uma discussão com pais e funcionários sobre os princípios da } \\
\text { educação integral, sobre o programa Mais Educação e após foi feito uma } \\
\text { reformulação do PPP, inserindo as oficinas que a escola irá trabalhar e } \\
\text { seus objetivos foi incluindo teatro e dança. }\end{array}$ \\
\hline Coordenador 05 & $\begin{array}{l}\text { A pintura, a música instrumental de corda, atletismo, incentivo ao } \\
\text { acompanhamento pedagógico. }\end{array}$ \\
\hline Coordenador 07 & $\begin{array}{l}\text { A parte burocrática referente às normativas e também seleção de alunos } \\
\text { junto aos professores, seleção das atividades, seleção de monitores e } \\
\text { preparo dos mesmos. }\end{array}$ \\
\hline Coordenador 09 & $\begin{array}{l}\text { Reorganização dos horários e dinâmicos da escola, reorganização dos } \\
\text { conteúdos dos competentes para que este seja uma continuidade no contra } \\
\text { turno. }\end{array}$ \\
\hline Coordenador 11 & $\begin{array}{l}\text { Reformular um documento, construir metas, delegar ações é muito fácil, o } \\
\text { problema é fazer cumprir com funcionalidade e verdadeiramente fazer } \\
\text { mudar a vida do aluno, para isso precisa-se de investimento. }\end{array}$ \\
\hline Coordenador 13 & $\begin{array}{l}\text { É difícil pois o PPP da escola é feito só para ter o documento e apresentar } \\
\text { para a SEDUC. }\end{array}$ \\
\hline Coordenador 15 & Nenhuma. \\
\hline Coordenador 17 & $\begin{array}{l}\text { A principal delas é a humanização da equipe da escola para recepção da } \\
\text { "jornada ampliada" }\end{array}$ \\
\hline Coordenador 18 & Foram realizados estudos para reformulação do PPP, regimento escolar \\
\hline
\end{tabular}




\begin{tabular}{|l|l|}
\hline & para inserir a Educação Integral. \\
\hline Coordenador 20 & $\begin{array}{l}\text { Orientação do embasamento legal para ser inserido no PPP, } \\
\text { acompanhamento do processo de reelaboração. }\end{array}$ \\
\hline Coordenador 24 & $\begin{array}{l}\text { Ações para oficinas diversas; seleção dos alunos; seleção dos monitores; } \\
\text { organização do espaço/horário; organização da oferta da alimentação. }\end{array}$ \\
\hline
\end{tabular}

Fonte: Elaborado pelos pesquisadores

Diante das respostas obtidas, cabe alguns questionamentos: Como materializar um projeto quando educadores acreditam que "a principal delas é a humanização da equipe da escola para recepção da jornada ampliada? Se o PPP da escola tornou-se apenas um instrumento burocrático a ser apresentado aos técnicos da SEDUC, quais as possibilidades de efetivação da educação integral?

Assim, o acréscimo de horas na jornada escolar com atividades de pintura, música instrumental de corda, atletismo, incentivo ou acompanhamento pedagógico não expressam necessariamente a materialização da educação integral. No entanto, sua efetivação implica na superação de uma perspectiva reducionista, utilitarista e assistencialista da proposta em tela. O conhecimento das propostas construídas ao longo da história é o primeiro passo para que se possa realmente efetivá-la.

Prosseguindo na análise das respostas, observe-se que as respostas obtidas junto aos diretores não são distantes daquelas dadas pelos coordenadores.

QUADRO 04- Gestão Escolar da Educação Integral- Diretores

\begin{tabular}{|l|l|}
\hline Participantes & $\begin{array}{l}\text { 2. A dinâmica da Implementação de um Programa de Educação Integral } \\
\text { requer diversas ações, dentre elas, a reformulação do Projeto Político } \\
\text { Pedagógico da escola. Cite as que você como Gestor/Coordenador } \\
\text { desenvolveu para a efetivação do referido Programa. }\end{array}$ \\
\hline Diretor 4 & $\begin{array}{l}\text { Mudanças gerais em relação ao contra turno: o ensino espanhol, ensino } \\
\text { religioso e outros trabalhos com projetos. }\end{array}$ \\
\hline Diretor 5 & $\begin{array}{l}\text { Aulas dinâmicas e principalmente aulas teóricas/práticas para vivenciar o } \\
\text { aprendizado. }\end{array}$ \\
\hline Diretor 8 & $\begin{array}{l}\text { Música, dança, jardinagem e reforço de matemática e português. } \\
\text { Discussão para implementação efetiva da educação integral, juntamente com a } \\
\text { comunidade escolar. }\end{array}$ \\
\hline Diretor 18 15 & $\begin{array}{l}\text { Reunião com os pais registrado em ata e depois colocado no PPP, como } \\
\text { atendimento ao baixo desempenho. }\end{array}$ \\
\hline Diretor 19 & $\begin{array}{l}\text { Estou há 9 meses na gestão e não tivemos ainda a realização do programa na } \\
\text { escola por falta dos recursos em conta. }\end{array}$ \\
\hline Diretor 20 & $\begin{array}{l}\text { O programa de Educação Integral na escola foi elaborado de acordo com as } \\
\text { necessidades mais urgentes como leitura e interpretação com apoio da } \\
\text { comunidade escolar. }\end{array}$ \\
\hline Diretor 21 & $\begin{array}{l}\text { Uma das nossas questões foi não rotular o menino, com o mais educação e } \\
\text { sim como aluno da escola qual for o período que ele estiver e a instituição. }\end{array}$ \\
\hline Diretor 24 & $\begin{array}{l}\text { Mudança de horário de funcionário, mudança de horário do pessoal da } \\
\text { cozinha e porteiros. }\end{array}$ \\
\hline
\end{tabular}

Fonte: Elaborado pelos pesquisadores

Considerando que o conhecimento é o instrumento básico de ação do homem sobre a natureza, é preciso ressaltar que não é qualquer tipo de conhecimento, mas se levarmos em conta a educação escolar trata-se do conhecimento científico. Ora, seria as propostas de educação integral uma forma de transmissão do conhecimento científico? Mudanças gerais 
em relação ao contra turno, com a inclusão do ensino de espanhol, ensino religioso e outros trabalhos com projetos seria uma forma de resposta para o questionamento?

A questão que se coloca, então, é a seguinte: o que muda com a introdução da educação integral ofertada pelo Estado? A música, dança, jardinagem e reforço de matemática e português configuram a oferta de educação integral ou trata-se apenas de preenchimento do tempo ampliado na escola? Como ignorar que há casos em que não ocorre a efetivação do programa por falta de recursos? Qual o significado de "aulas dinâmicas" sem o domínio rigoroso dos fundamentos da educação integral?

As respostas colocam em evidência a tarefa imediata da educação escolar (nem sempre alcançada) de tornar possível um maior grau de consciência, ou seja, de conhecimento e compreensão da realidade historicamente construída pelos homens. Dito de outra forma, o acesso ao conhecimento historicamente produzido pelos homens não deve ser privilégio de poucos.

A respeito do Currículo, quando indagados, coordenadores e diretores demonstram as limitações de toda ordem na implantação do programa.

QUADRO 05- Desenvolvimento do currículo integrado na coordenação pedagógica

\begin{tabular}{|c|c|}
\hline Participantes & $\begin{array}{l}\text { 3. O desenvolvimento de um Currículo na perspectiva da Educação } \\
\text { Integral requer além da ampliação de tempos e espaços, a ampliação } \\
\text { de oportunidades de qualificação. Isso implica em um desenho da } \\
\text { organização das atividades. O que foi realizado em sua Gestão/ } \\
\text { Coordenacão para materializar essas oportunidades/atividades? }\end{array}$ \\
\hline Coordenador 1 & $\begin{array}{l}\text { Busca de parceiros disponíveis para a realização e desenvolvimento das } \\
\text { atividades. }\end{array}$ \\
\hline Coordenador 3 & $\begin{array}{l}\text { Procuramos sempre trabalhar com monitores (acadêmicos) dentro das } \\
\text { habilidades e formação para as oficinas e apoio técnico. }\end{array}$ \\
\hline Coordenador 4 & $\begin{array}{l}\text { Dialogou-se com os servidores e pais para definirmos os melhores } \\
\text { horários para a realização das oficinas. }\end{array}$ \\
\hline Coordenador 5 & $\begin{array}{l}\text { As atividades estão distribuídas em seis áreas, com } 4 \text { turmas, onde os } \\
\text { alunos estudam sete horas por dia em espaços improvisados. }\end{array}$ \\
\hline Coordenador 7 & $\begin{array}{l}\text { Na minha escola temos o Programa Mais Educação. A Coordenadora se } \\
\text { interage com os professores e monitores para que o reforço venha de } \\
\text { dentro da sala de aula, o lúdico dos conteúdos é trabalhado com os } \\
\text { alunos do programa Mais Educação. }\end{array}$ \\
\hline Coordenador 11 & Foram feitas propostas, mas não se materializou. \\
\hline Coordenador 13 & $\begin{array}{l}\text { Foi organizado horário de atividades de pessoal de cozinha, monitores e } \\
\text { construção de salas para atender os estudos. }\end{array}$ \\
\hline Coordenador 14 & $\begin{array}{l}\text { As atividades selecionadas são de acordo ao que é ofertado pelo MEC de } \\
\text { forma regional sendo que uma é obrigatória e as outras são selecionadas } \\
\text { de forma a contempladas os estímulos a coordenação motora, } \\
\text { sociabilidade e características regionais. }\end{array}$ \\
\hline Coordenador 15 & Não respondeu \\
\hline Coordenador 16 & $\begin{array}{l}\text { Os professores participam de formação oferecidas pela SEDUC, } \\
\text { professores do projeto estavam em constante contato com os professores } \\
\text { do regular que se materializasse o conhecimento. }\end{array}$ \\
\hline Coordenador 17 & $\begin{array}{l}\text { Oportunidades de qualificação essa é a palavra, qualificar para produzir. } \\
\text { No início a dança fez muito sucesso na escola e o trabalho com mídias, } \\
\text { temos registro dessas palavras, enquanto um grupo de professores } \\
\text { aplicaram as atividades quando passamos para os monitores a qualidade. }\end{array}$ \\
\hline Coordenador 18 & $\begin{array}{l}\text { Como coordenador do programa Mais Educação, não vejo o programa } \\
\text { como educação integral. Minha contribuição foi escolher junto com os }\end{array}$ \\
\hline
\end{tabular}




\begin{tabular}{|l|l|}
\hline & $\begin{array}{l}\text { professores e coordenação pedagógica os macros campo/atividades, } \\
\text { seleção dos monitores planejamento com monitores. }\end{array}$ \\
\hline Coordenador 19 & $\begin{array}{l}\text { Oficinas de alfabetização e leitura; oficinas de matemática básica, além } \\
\text { das oficinas cadastradas no programa Mais Educação; oficinas de } \\
\text { conscientização ambiental. }\end{array}$ \\
\hline Coordenador 20 & $\begin{array}{l}\text { Na seleção de atividades que antecedem as maiores necessidades da } \\
\text { comunidade escolar. }\end{array}$ \\
\hline Coordenador 21 & Até o momento nada, estamos sem recurso. \\
\hline Coordenador 22 & $\begin{array}{l}\text { Buscamos parcerias com escola vizinha para aulas de canto coral e com } \\
\text { ONG para aulas de karatê. }\end{array}$ \\
\hline Coordenador 23 & $\begin{array}{l}\text { Orientação quanto a estudo dos cadernos pedagógicos, embasamento } \\
\text { legal, diagnósticos as necessidades, planejar as estratégias, e elaborar em } \\
\text { equipe os caminhos que a escola deseja percorrer e como, quando e onde } \\
\text { deseja chegar. }\end{array}$ \\
\hline Coordenador 24 & \begin{tabular}{l} 
Ainda nada sobre currículo. \\
\hline
\end{tabular}
\end{tabular}

Fonte: Elaborado pelos pesquisadores

Dos vinte e quatro coordenadores entrevistados, quatro afirmaram que não se materializaram iniciativas curriculares para educação integral em suas respectivas unidades escolares; o coordenador $\mathrm{n}^{\circ} 5$ afirmou: "os alunos estudam sete horas por dia em espaços improvisados". Ora, o desdobramento de casos como os relatados é a desqualificação e esvaziamento das funções da escola pública. Dito de outra forma, não basta a existência da escola para a transmissão do saber sistematizado, mas faz-se necessário viabilizar as condições de sua transmissão.

Para além do que foi observado, ressalte-se também, que algumas medidas tomadas, a escola tornou-se um espaço disputado ONGs e outras instituições que se tornam "parceiras" da atividade educativa. Dessa forma, reforça-se a omissão do Estado no estabelecimento de espaços adequados para a constituição da educação escolar. A respeito da questão curricular, Saviani apresenta as seguintes contribuições:

Essa questão tem desdobramentos ainda de outras ordens. Assim, por exemplo, em nome desse conceito ampliado de currículo, a escola tornouse um mercado de trabalho disputadíssimo pelos mais diferentes tipos de profissionais (nutricionistas, dentistas, fonoaudiólogos, psicólogos artistas, assistentes sociais etc.), e uma nova inversão opera-se. De agência destinada a atender o interesse da população pelo acesso ao saber sistematizado, a escola passa a ser uma agência a serviço de interesses corporativistas ou clientelistas. E neutraliza-se assim, mais uma vez, agora por outro caminho, o seu papel no processo de democratização (SAVIANI, 2003, p. 17).

Cabe ressaltar que neste cenário, o acesso ao conhecimento ocorre de forma profundamente desigual e seletiva. Tudo isso, entretanto, é legitimado pelo discurso do respeito às diferenças culturais, pela democratização do acesso ao conhecimento, facilitada pelas tecnologias da informação e pela subordinação dos objetivos da educação escolar aos interesses do mercado.

QUADRO 06- Desenvolvimento do currículo integrado na Gestão escolar

\begin{tabular}{|l|l|l|}
\hline Participantes & $\begin{array}{l}\text { 3. O desenvolvimento de um Currículo na perspectiva da Educação } \\
\text { Integral requer além da ampliação de tempos e espaços, a ampliação de } \\
\text { oportunidades de qualificação. Isso implica em um desenho da } \\
\text { organização das atividades. O que foi realizado em sua Gestão/ }\end{array}$ \\
\hline
\end{tabular}




\begin{tabular}{|c|c|}
\hline & Coordenação para materializar essas oportunidades/atividades? \\
\hline Diretor 1 & $\begin{array}{l}\text { Pesquisa junto a comunidade escolar para ver as melhores opções, observando } \\
\text { as possibilidades da escola enquanto espaço físico e recursos humanos. }\end{array}$ \\
\hline Diretor 2 & $\begin{array}{l}\text { As capacitações acontecem a nível de CRE. Apresentando atividades exitosas } \\
\text { das escolas componentes. }\end{array}$ \\
\hline Diretor 3 & $\begin{array}{l}\text { Houve a promoção de reuniões, encontros e entrevistas para montar a equipe e } \\
\text { dar início aos planejamentos para identificação das reais condições da escola e } \\
\text { o que a comunidade apresentaria para somar ao desenvolvimento do } \\
\text { programa. }\end{array}$ \\
\hline Diretor 4 & $\begin{array}{l}\text { Nomear o coordenador dos programas e lhe dar total apoio para a } \\
\text { concretização das atividades. }\end{array}$ \\
\hline Diretor 5 & $\begin{array}{l}\text { Não foi desenvolvido nenhum tipo de atividade pois, a Educação integral está } \\
\text { parada esse ano, esperamos retornar no próximo ano. }\end{array}$ \\
\hline Diretor 6 & $\begin{array}{l}\text { Apenas reuniões da CRE e SEDUC destinadas ao coordenador e diretor. } \\
\text { Precisamos de formação continuada para toda equipe da escola. }\end{array}$ \\
\hline Diretor 7 & $\begin{array}{l}\text { No Mais Educação, nas oficinas e principalmente, a oficina de } \\
\text { acompanhamento pedagógico trocam informações com os professores de sala } \\
\text { de aula. }\end{array}$ \\
\hline Diretor 8 & $\begin{array}{l}\text { Sempre é dado um jeitinho, tivemos parcerias com pessoas que cederam os } \\
\text { espaços. }\end{array}$ \\
\hline Diretor 9 & $\begin{array}{l}\text { Formação através da SEDUC, seleção de atividades no programa compatível a } \\
\text { clientela e espaço escolar. Ementa do programa. }\end{array}$ \\
\hline Diretor 10 & $\begin{array}{l}\text { Fizemos reuniões e estudos do currículo e foram feitos algumas considerações } \\
\text { e reflexões sobre nossa realidade. }\end{array}$ \\
\hline Diretor 11 & Adequar as salas e oferecer espaço para jogos, como tênis de mesa e capoeira. \\
\hline Diretor 12 & $\begin{array}{l}\text { A escola mesmo sem as condições necessária como: biblioteca adequada } \\
\text { quadra de esporte laboratórios entre os espaços foi contemplada com o Mais } \\
\text { educação daí então acrescentando no currículo. }\end{array}$ \\
\hline Diretor 13 & $\begin{array}{l}\text { Reunião com pais, palestras com os alunos, e reorganização do espaço físico e } \\
\text { também reunião com os servidores de apoio. }\end{array}$ \\
\hline Diretor 14 & $\begin{array}{l}\text { Ambientes ampliados para execução e reorganização de outros para atender } \\
\text { aulas de dança e música. }\end{array}$ \\
\hline Diretor 15 & $\begin{array}{l}\text { Estudos e trocas de experiências acerca das atividades que devem ser } \\
\text { desenvolvidas na Educação Integral. }\end{array}$ \\
\hline Diretor 16 & $\begin{array}{l}\text { A discussão em conjunto entre os professores e monitores sobre um currículo } \\
\text { diversificado; A escolha de conteúdos que sejam que sejam necessários à } \\
\text { formação do aluno. A parceria com os monitores para melhorar os alunos. }\end{array}$ \\
\hline Diretor 17 & $\begin{array}{l}\text { Aplicação de questionários para conhecimento de fato da realidade e } \\
\text { necessidade para escolha das atividades. }\end{array}$ \\
\hline Diretor 18 & $\begin{array}{l}\text { O funcionamento da escola foi adequada para o atendimento do programa, } \\
\text { onde a coordenadora, no horário de planejamento verifica os conteúdos } \\
\text { trabalhado no bimestre. }\end{array}$ \\
\hline Diretor 19 & Não respondeu. \\
\hline Diretor 20 & $\begin{array}{l}\text { As atividades foram organizadas com poucos recursos e espaços pequenos. } \\
\text { Mas aconteceram e temos obtido êxito neste trabalho. }\end{array}$ \\
\hline
\end{tabular}




\begin{tabular}{|l|l|}
\hline Diretor 21 & $\begin{array}{l}\text { Um dos itens foi fazer com que eles estavam para aprender com o monitor e o } \\
\text { corpo docente pudesse auxiliar este monitor. }\end{array}$ \\
\hline Diretor 22 & $\begin{array}{l}\text { Utilizamos os recursos para adquirir os materiais pertinentes ao projeto e } \\
\text { realizamos o acompanhamento pedagógico e disciplinar. }\end{array}$ \\
\hline Diretor 23 & $\begin{array}{l}\text { Importante respeitar o currículo, adequando com a realidade dos alunos } \\
\text { atendidos. É preciso que o gestor de todo o apoio na realização das ações do } \\
\text { macro campos. }\end{array}$ \\
\hline Diretor 24 & Criamos salas ambientes. Desocupamos espaços ociosos. \\
\hline
\end{tabular}

Fonte: Elaborado pelos pesquisadores

Diante das respostas obtidas, permite, de forma muito sintética, explicitar que o pressuposto basilar do Programa Mais Educação não disputa um projeto societário antagônico à modernização conservadora do capital. Trata-se de uma proposta de "melhoria" da educação por meio das parcerias com o setor privado ampliando a dualidade estrutural da educação. As respostas deixam a impressão que estamos diante de mecanismos protelatórios.

Ao abordar as políticas públicas para educação na primeira década do século XXI, Frigotto analisa a omissão do Estado da seguinte forma:

Reitero aqui, também, que o problema não está na necessidade de que se reveste a maior parte dessas ações e políticas, mas, sim, na forma de sua gestão e na concepção que as orientam. Com respeito à gestão, o viés contraditório dá-se por serem tais ações e políticas, em grande parte, pautadas na opção pelas parcerias do público com o privado e dentro de uma perspectiva daquilo que Saviani denominou pela pedagogia de resultados, sem a disputa pela concepção que as orienta. Com isso, o Estado em vez de alargar o fundo público na perspectiva de atendimento a políticas públicas de caráter universal, fragmenta as ações em políticas focais, sem alterar substancialmente as suas determinações. E, dentro dessa lógica, é dada ênfase aos processos pedagógicos, são desenvolvidos mediante a pedagogia das competências (FRIGOTTO, 2011, p. 244-245).

Diante da hegemonia liberal no âmbito das políticas de Estado, como compreender o direito à educação? Qual o significado das respostas de diretores das unidades escolares? Qual o interesse do Estado em promover uma educação que contemple uma formação sólida dos filhos da classe trabalhadora?

Desnecessário dizer que em nossa sociedade o compromisso com a formação integral dos filhos da classe trabalhadora por parte dos agentes da burguesia não passa de discurso vazio. Nunca é demais lembrar que em tempos de acumulação alicerçada no toyotismo, caracterizado pela automação, microeletrônica e trabalho flexível, os trabalhadores perdem a visão do todo. Nesse sentido, a proposta de educação integral acaba se revestindo de um caráter assistencialista que objetiva tirar crianças da rua. No entanto, para tal empreitada o Estado acaba por delegar à "sociedade civil" a tarefa de auxiliar a escola que não apresenta as condições necessárias como: "biblioteca adequada quadra de esporte; laboratórios entre os espaços".

Nessa direção, a educação é lançada a caridade pública, que em nome da flexibilidade do mercado se descentraliza os gastos do Estado, por meio da responsabilização da sociedade civil. Assim, a função da escola, enquanto produtora e transmissora do conhecimento clássico, sistematizado pela humanidade, esvazia-se em prol 
de uma política assistencialista, pauperizada pela hipertrofia do saber elaborado e pela intensificação do Estado mínimo.

QUADRO 07- Metodologias e Práticas Escolares operacionalizadas pela coordenação pedagógica

\begin{tabular}{|c|c|}
\hline Participantes & $\begin{array}{l}\text { 04- Quais Metodologias e quais Práticas Escolares foram adotadas } \\
\text { para a operacionalização do Currículo sob a sua Gestão/Coordenação } \\
\text { ? }\end{array}$ \\
\hline Coordenador 1 & $\begin{array}{l}\text { Metodologia- conversa com a comunidade. } \\
\text { Praticas- planejamento com professores e monitores, apresentação } \\
\text { contínua de trabalhos desenvolvidos. }\end{array}$ \\
\hline Coordenador 2 & Elaboração do plano de curso. \\
\hline Coordenador 3 & Tentamos usar o máximo que possível com o lúdico. \\
\hline Coordenador 4 & $\begin{array}{l}\text { Buscou-se parcerias com locais de lazer como cinemas e balneários e } \\
\text { instituições educativas: Facimed, UNESC. }\end{array}$ \\
\hline Coordenador 5 & $\begin{array}{l}\text { Não foi alterado o currículo, o que houve foi uma adaptação, estamos há } 4 \\
\text { meses no programa Mais Educação, que nos foi apresentado apenas } \\
\text { mediante uma apostila e nada mais. }\end{array}$ \\
\hline Coordenador 6 & $\begin{array}{l}\text { Melhorar o atendimento dos alunos, estudos em busca de novos } \\
\text { conhecimentos. }\end{array}$ \\
\hline Coordenador 7 & $\begin{array}{l}\text { Os trabalhos eram desenvolvidos em equipes, jornada ampliada de } \\
\text { atividades diversificadas de acordo com pais e comunidade. }\end{array}$ \\
\hline Coordenador 8 & Atividades lúdicos e práticas da vivência do alunado. \\
\hline Coordenador 9 & $\begin{array}{l}\text { Planejar a organização curricular (as disciplinas transversais) e separar a } \\
\text { teoria ou melhor, trabalhar a teoria dificultosamente com a prática (quis } \\
\text { dizer que é muito difícil colocar a teoria com a prática). }\end{array}$ \\
\hline Coordenador 10 & $\begin{array}{l}\text { Não estipulamos metodologias, são trabalhadas como reforço. Os } \\
\text { professores opinam o que precisa ser trabalhado. }\end{array}$ \\
\hline Coordenador 11 & Não respondeu. \\
\hline Coordenador 12 & $\begin{array}{l}\text { Projetos aluno/monitor parceria com monitores e professores de } \\
\text { matemática e Língua Portuguesa. Planejamento coletivo dos monitores, } \\
\text { oficinas, teatro, dança, orientação de estudo e leitura, futsal, atletismo, } \\
\text { horta e rádio escolar. }\end{array}$ \\
\hline Coordenador 13 & $\begin{array}{l}\text { Parceria com entidades local; horário de planejamento; acompanhamento } \\
\text { das atividades pedagógicas; registros das ações. }\end{array}$ \\
\hline Coordenador 14 & $\begin{array}{l}\text { Inscrições pelo site do MEC e luta por arranjar espaço e salas para a } \\
\text { realização das atividades. O Mais Educação é discriminado dentro da } \\
\text { rotina escolar. }\end{array}$ \\
\hline Coordenador 15 & Não respondeu \\
\hline Coordenador 16 & $\begin{array}{l}\text { Aulas dinâmicas com metodologias diferenciadas, mesa redonda, vistas, } \\
\text { etc. }\end{array}$ \\
\hline Coordenador 17 & $\begin{array}{l}\text { Reuniões (no que diz respeito a Educação Integral); elaboração de } \\
\text { cronograma com horários e atividades; participação dos alunos nos } \\
\text { eventos culturais da escola e comunidade; motivação por meio da } \\
\text { Coordenadora a participar das atividades }\end{array}$ \\
\hline Coordenador 18 & $\begin{array}{l}\text { Reuniões com os demais funcionários e gestores e a coordenação } \\
\text { pedagógica. }\end{array}$ \\
\hline Coordenador 19 & $\begin{array}{l}\text { Adotei as sugeridas no manual operacional do Mais Educação. Os alunos } \\
\text { no contra turno tem acesso a oficina de estudos dirigidos, artes e esportes. }\end{array}$ \\
\hline Coordenador 20 & $\begin{array}{l}\text { Manter o máximo de integração entre turnos participando de projetos } \\
\text { comuns. }\end{array}$ \\
\hline Coordenador 21 & Avaliação com a comunidade escolar, reunião e debates. \\
\hline Coordenador 22 & Foram organizados encontros da equipe pedagógica no horário de almoço, \\
\hline
\end{tabular}




\begin{tabular}{|l|l|}
\hline & palestra e grupo de estudo. \\
\hline Coordenador 23 & Pesquisas, leituras, reflexão e reelaboração. \\
\hline Coordenador 24 & $\begin{array}{l}\text { Não houve ainda nada nesse sentido. Não houve abertura para isso. Difícil } \\
\text { de realizar. }\end{array}$ \\
\hline
\end{tabular}

Fonte: Elaborado pelos pesquisadores

Conforme os dados obtidos na entrevista, é possível perceber a fragilidade da proposta no "chão da escola". Não se trata de culpar diretores, coordenadores ou professores pelas dificuldades enfrentadas pelos Programas de Educação Integral. A questão que se coloca passa pela formação e pelas condições de trabalho dos envolvidos. Observe que um coordenador afirma "que não foi alterado o currículo" e que ainda o programa foi apresentado na escola apenas por "uma apostila e nada mais". Fica a impressão que a forma de materialização ocorre por meio de improvisações e da boa vontade da equipe responsável pela escola.

Ora, um projeto de superação radical das desigualdades estruturais da sociedade capitalista deve levar em questão da educação escolar. Não é o propósito do presente trabalho defender a bandeira da escola como redentora social ou como instituição que levará necessariamente a ruptura da ordem burguesa. No entanto, é importante que se diga, o núcleo das propostas burguesas para o campo da educação escolar, atribuem o papel de propulsora das transformações sócias por meio da chamada pedagogia de projetos, prática do empreendedorismo, ações voluntárias, etc.

Assim sendo, o que esperar do trabalho pedagógico de uma escola que precisa buscar "parcerias" no mercado? Qual o sentido de trabalhar sem metodologias estipuladas, mas apenas com oferta de aulas de reforço? As ações descritas tornarão "possível um maior grau de consciência da realidade da qual nós, seres humanos, somos parte e na qual atuamos teórica e praticamente?" (RIBEIRO, 1991, p. 40).

Ora, uma hipótese plausível a partir da percepção de diretores e coordenadores é que a educação integral e a melhoria da qualidade da oferta de ensino tem sido um artifício retórico no discurso oficial dos órgãos do Estado. Diante dos fatos, há que se reconhecer que a escola mantida pelo Estado não está dotada, de fato, das condições suficientes para assumir as novas funções sociais que vem incorporando. Por isso, a necessidade de reivindicar uma escola com estrutura, equipamento e educadores que possam cobrir todas as necessidades do desenvolvimento da juventude.

QUADRO 08- Metodologias e Práticas Escolares operacionalizadas pela Gestão Escolar

\begin{tabular}{|l|l|}
\hline Participantes & $\begin{array}{l}\text { 04- Quais Metodologias e quais Práticas Escolares foram adotadas para } \\
\text { a operacionalização do Currículo sob a sua Gestão/Coordenação? }\end{array}$ \\
\hline Diretor 1 & $\begin{array}{l}\text { Estudo das propostas curriculares do estado e análise da realidade local pelos } \\
\text { gestores e professores. }\end{array}$ \\
\hline Diretor 2 & $\begin{array}{l}\text { A coordenação do Mais Educação trabalha efetivamente com o planejamento } \\
\text { com os monitores. Há a sensibilização aos pais para mandar seus filhos à } \\
\text { escola. }\end{array}$ \\
\hline Diretor 3 & $\begin{array}{l}\text { Identificar as fraquezas e potencializar com ações e práticas buscando } \\
\text { profissionais com habilidades visando minimizar os problemas de defasagem } \\
\text { dessa clientela. }\end{array}$ \\
\hline Diretor 4 & $\begin{array}{l}\text { Ampliação da culminância dos projetos para a comunidade, assim como } \\
\text { colocar em prática todo o plano de aplicação. }\end{array}$ \\
\hline Diretor 5 & $\begin{array}{l}\text { Esse ano não está sendo desenvolvida a Educação Integral na escola em que } \\
\text { trabalho. }\end{array}$ \\
\hline
\end{tabular}




\begin{tabular}{|l|l|}
\hline Diretor 6 & As metodologias são oficinas - jogos e aulas práticas. \\
\hline Diretor 7 & $\begin{array}{l}\text { Trabalho em grupo, contra período, várias oficinas ao mesmo tempo. Todos } \\
\text { passam por todas oficinas, escolhida pelos pais dos alunos. }\end{array}$ \\
\hline Diretor 8 & Não respondeu. \\
\hline Diretor 9 & Referencial curricular, orientações para desenvolver as atividades no manual. \\
\hline Diretor 10 & Trabalhamos com reforço em horário opostos. \\
\hline Diretor 11 & $\begin{array}{l}\text { Reforços em matemática e português, atividades esportivas e jogos } \\
\text { interativos. }\end{array}$ \\
\hline Diretor 12 & $\begin{array}{l}\text { As metodologias foram divididas em macro-campos trabalhando em } \\
\text { consonância com os professores das respectivas disciplinas. }\end{array}$ \\
\hline Diretor 13 & $\begin{array}{l}\text { Formação continuada, estudos das resoluções e portarias. Reformulações do } \\
\text { PP. }\end{array}$ \\
\hline Diretor 14 & $\begin{array}{l}\text { O currículo do programa e pre-estabelecido pelo MEC, vinculamos algumas } \\
\text { oficinas que vinham de encontro aos anseios dos alunos. Outro uma grande } \\
\text { interação com o PROEMI (Programa Ensino Médio Inovador) }\end{array}$ \\
\hline Diretor 15 & Principalmente projetos interdisciplinares com ênfase nas áreas críticas. \\
\hline Diretor 16 & $\begin{array}{l}\text { Aulas com material concreto; recreio dirigido; Ajuda dos monitores nas } \\
\text { tarefas escolares; participação de alguns pais na leitura. }\end{array}$ \\
\hline Diretor 17 & Não respondeu. \\
\hline Diretor 18 & $\begin{array}{l}\text { Cada profissional (professores) trabalha a metodologia que mais se identifica } \\
\text { usando avaliação continua e paralela. }\end{array}$ \\
\hline Diretor 19 & Não respondeu. \\
\hline Diretor 20 & $\begin{array}{l}\text { O currículo está sendo modificado-melhorado para melhor atender a } \\
\text { comunidade escolar priorizando o aluno no seu desenvolvimento integral. }\end{array}$ \\
\hline Diretor 21 & Planejar e monitorar o professor juntos. \\
\hline Diretor 22 & $\begin{array}{l}\text { Acompanhamento do horário de planejamento, orientação aos professores e } \\
\text { disposição da estrutura em melhoria diariamente. }\end{array}$ \\
\hline Diretor 23 & $\begin{array}{l}\text { Liberal, adequando o currículo com a realidade da comunidade atendida com } \\
\text { aulas práticas de incentivo ao esporte, artes, respeitando ao meio ambiente, } \\
\text { trabalhando com jardins e hortas na escola, produzindo para se consumir, etc. }\end{array}$ \\
\hline Conscientização e participação de todos. \\
\hline piretor 24
\end{tabular}

Fonte: Elaborado pelos pesquisadores.

Constata-se que a "qualidade da educação" atribuída ao progressivo avanço da Educação Integral em Rondônia não se revela nas respostas dos diretores. Afinal, como definir as metodologias propostas quando cada profissional trabalha com aquela que mais se identifica? A resposta sugere uma demonstração do desconhecimento dos fundamentos que orientam a prática educativa. Ora, o funcionamento da escola supõe que os educadores tenham pelo domínio dos conteúdos e dos métodos adequados para sua transmissão. Ainda que ocorra a existência da formação continuada de professores e estudos das resoluções e portarias, faz-se necessário verificar as formas que ocorrem estas ocorrem.

Não foi propósito do presente trabalho abordar a questão da formação de professores, mas a julgar pelas respostas, percebe-se a inconsistência e fragilidade acerca da educação integral. Também não se pode esquecer que no contexto do processo acelerado de internacionalização da economia, nos moldes atuais da produção capitalista, observa-se uma perspectiva contraditória às leis, demonstrando a ampliação do acesso à 
escola ao mesmo tempo em que precarizam-se os processos educativos, que resultam em mera oportunidade de certificação, os quais não asseguram nem inclusão, nem permanência (KUENZER, 2006, p. 880).

Isto posto, a ampliação da jornada escolar ou a educação integral, ainda que necessárias e urgentes, não implica necessariamente na garantia de que os alunos terão acesso ao conhecimento historicamente produzido pela humanidade. O aumento da demanda deverá ser acompanhado pelas condições adequadas do espaço escolar e aprimoramento do trabalho pedagógico, bem como por medidas que tornem possível a permanência dos jovens no ambiente da escola.

\section{CONSIDERAÇÕES FINAIS}

Diante do que já foi exposto, abordar a questão da educação integral implica em considerar a questão do tempo, com a ampliação da jornada escolar; e a variável espaço físico adequado da escola, além da formação dos educadores que trabalham diretamente na escola. Nesse sentido, verificou-se alguns problemas para a materialização da educação integral, a saber: em primeiro lugar, a indeterminação do significado atribuído a suposta "formação completa", seus decorrentes pressupostos e metodologias de trabalho, vagas e destituídos de objetivos claros; em segundo, observa-se a ausência de recursos em inúmeras escolas, o que leva as equipes gestoras à improvisação de atividades extracurriculares.

Percebe-se, claramente, a partir dos depoimentos de diretores e coordenadores, que a finalidade do governo teria sido resolver paliativamente, problemas sociais gerados pela ausência de políticas sociais. Nesse sentido, além do ensino, a escola seria o espaço para retirar das ruas as crianças em condições de vulnerabilidade social. No entanto, diante das carências de adequação do prédio e da fragilidade do entendimento acerca da educação integral, a escola de tempo integral acaba não ofertando que é proclamado: o ensino de qualidade. Os desdobramentos da prática verificada materializam de forma direta na mistificação e no fortalecimento da premissa que a educação integral se constitui apenas enquanto expansão da jornada escolar e na consagração do assistencialismo

Como se pode observar, para a efetiva materialização da educação integral no Brasil como política de Estado e modelo de gestão, deve-se reconstruir a escola existente; não é suficiente apenas pequenas reformas ou arranjos improvisados que signifiquem a "maquiagem" do prédio para adequação de um projeto que muitos sequer sabem os diferentes significados que lhe podem ser atribuídos. É preciso muito mais. É necessário que o Estado não se paute pela contenção de despesas na organização da educação que atenda aos interesses das classes trabalhadoras. É urgente que os envolvidos no projeto tenham acesso a formação que lhe propicie atuar de forma eficiente.

Nessa perspectiva, é fundamental uma formação sólida, capaz de instrumentalizar teórica e metodologicamente o processo de ensino-aprendizagem e seus determinantes na formação multilateral dos alunos. Dessa forma, um dos desafios que se coloca a educação integral está relacionado à formação dos profissionais da escola, que em muitos casos se concretiza apenas como uma mera formalidade, um ato cartorário. No entanto, tal tarefa não diz respeito apenas aos profissionais da escola, mas, todos aqueles comprometidos com a educação dos filhos da classe trabalhadora que devem arrancar do Estado às condições materiais para tal empreitada. 
Por fim, as formas de materialização das políticas de educação integral no estado de Rondônia, encontram sérias limitações, mas ao considerarmos a educação um instrumento de criação das condições necessárias para a superação dessa ordem societária, e sendo ela a via de acesso ao conhecimento humano sistematizado, se faz necessário que essa seja reclamada pela a classe que vive do trabalho.

\section{REFERÊNCIAS}

BRASIL. Lei de Diretrizes e Bases da Educação Nacional. Lei número 9.394, 20 de dezembro de $1996 . \quad$ Disponível em: http://www.planalto.gov.br/ccivil_03/LEIS/L9394.htm.Acesso em 22/05/2012.

BRASIL. Decreto no 6.094, de 24 de abril de 2007. Diário Oficial da União, Brasília, 25 abr. 2007.

BRASIL. Ministério da Educação (MEC). Plano de Desenvolvimento da Educação (PDE): razões, princípios e programas. Brasília, [2007]. Disponível em: http://portal.mec.gov.br/arquivos/livro/. Acesso em: 20 março 2015.

BRASIL. Decreto $n^{\circ} 7.083$, de 27 de Janeiro de 2010. Dispõe sobre o Programa Mais Educação. Brasília, 2010. Disponível em: http://www.planalto.gov.br/ccivil_03/_ato20072010/2010/decreto/d7083.htm. Acesso em 01/02/2015.

FRIGOTTO, Gaudêncio. A produtividade da escola improdutiva. São Paulo, Cortez/Autores Associados, 1984.

FRIGOTTO, Gaudêncio. Os circuitos da história e o balanço da educação no Brasil na primeira década do século XXI. Revista brasileira de educação. Rio de Janeiro: Anped. v. $16, \mathrm{n}^{\mathrm{o}} 46,2011$, p. $235-254$

HOBSBAWM, E. Sobre história. São Paulo: Companhia das Letras, 1995.

KUENZER, Acácia. A educação profissional nos anos 2000: A dimensão subordinada das políticas de inclusão. Educ. Soc., Campinas, vol. 27, n. 96 - Especial, p. 877-910, out. 2006

LACERDA, Maria do Pilar. Apresentação. In: MOLL, Jaqueline et al. Caminhos da Educação Integral no Brasil: direito a outros tempos e espaços educativos. Porto Alegre: Penso, 2012. P. 17-18.

LEMME, Paschoal. A Educação na U.R.S.S. - 1953. Rio de Janeiro: Vitória, 1955.

MACIEL, A. C. Fundamentos da educação integral politécnica. In: MACIEL, A. C; WEIGEL, V. A. C. M; CIOFFI, L. C; BRAGA, R. M; FERRAZZO, G. Gestão da Educação Integral politécnica: uma proposta para o Brasil I. Porto Velho-RO, Ed. EDUFRO, 2013, p. 119-140.

O MANIFESTO DOS PIONEIROS DA EDUCAÇÃO NOVA: A RECONSTRUÇÃO EDUCACIONAL NO BRASIL - AO POVO E AO GOVERNO, 1932. Disponível em: http://www.pedagogiaemfoco.pro.br/heb07a.htm. Acesso em 09/10/2014.

MARX, Karl; ENGELS, Friedrich. Textos sobre educação e ensino. São Paulo: Cortez, 2004.

MARX, Karl e ENGELS, Friedrich. A ideologia alemã. São Paulo: Boitempo 2007.

RIBEIRO, Darcy. Nossa escola é uma calamidade. Rio de Janeiro: Salamandra, 1984.

RIBEIRO, Darcy. O livro dos CIEPs. Rio de Janeiro: Bloch, 1986. 
RIBEIRO, Maria Luisa Santos. Educação escolar e práxis. São Paulo: Iglu, 1991.

RODRIGUES, José. Educação politécnica. Disponível em: http://www.epsjv.fiocruz.br/dicionario/verbetes/edupol.html. Acesso em: 14 ago. 2012.

SAVIANI, Dermeval. O choque teórico da politecnia. Trabalho, Educação e Saúde, v. 1, n. 1, p. 131-152, 2003.

Autores Associados, 2003.

Pedagogia Histórico Crítica: primeiras aproximações. Campinas:

SECRETARIA DE ESTADO DA EDUCAÇÃO DE RONDÔNIA. Contratação de estagiários e formação de Comitê vão fortalecer Educação Integral Rondônia. Disponível em $<$ http://www.rondonia.ro.gov.br/2015/11/91237/ $>$ Data de acesso: 08/03/2016.

SECRETARIA DE ESTADO DA EDUCAÇÃO DE RONDÔNIA. Projeto Guaporé de Educação Integral. $2013 . \quad$ Disponível em: http://www.seduc.ro.gov.br/portal/index.php/noticias-all/1115-projeto-guapore-deeducacao-integral-atende-11-mil-alunos.html. Acesso em 11 de Março 2016.

SILVA, Jamerson Antônio de Almeida da; SILVA, Katharine Ninive Pinto. Concepto f integral education in More Education Program. Rev. Bras. Estud. Pedagog. Brasília, v 4, n. 238, $\operatorname{dez} 2013.2$ Disponível em: http://www.scielo.br/scielo.php?script=sci_arttext\&pid=S217666812013000300004\&lng=pt\&nrm=iso. Acesso em: 31/03/2015.

TEIXEIRA, Anísio. “Centro Educacional Carneiro Ribeiro". Rio de Janeiro, Revista Brasileira de Estudos Pedagógicos, vo.31, no. 73, jan-mar, 1959.

TEIXEIRA, Anísio. Pequena introdução à filosofia da educação: A escola progressiva ou a transformação da escola. São Paulo, Editora Nacional, 1968.

TEIXEIRA, A. S. Educação não é privilégio. 4. ed. São Paulo: Nacional, 1977.

\footnotetext{
${ }^{1}$ Professor do Departamento de Fundamentos da Educação - DFE/UEM

Email: marcooliveiragomes@yahoo.com.br

${ }^{2}$ Email: claudiapvh@ hotmail.com

${ }^{3}$ Email: geferrazzo@ hotmail.com
}

Recebido: março/16 Aprovado: dezembro/16 